\title{
Overexpression of the cancer-related DUSP1 gene in human obesity and its modulation by physical exercise
}

\author{
Abdelkrim Khadir", Ali Tiss, Jehad Abubaker, Mohamed Abu-farha, Said Dermime, Mohammed Dehbi \\ From Updates on Immunotherapy of Cancer and Immunoscore Symposium, part of the Sidra Symposia Series, \\ held in partnership with the Society for Immunotherapy of Cancer \\ Doha, Qatar. 22-23 January 2014
}

Obesity is a major risk factor for metabolic diseases and cancer. Lifestyle interventions in obesity reduce the risk for cancer. Aberrant regulation of dual specificity protein phosphatase 1 (DUSP1) was linked to obesity and cancer representing an attractive therapeutic target and to study the relationship between obesity and cancer. Here, we investigated the effects of a 3-month physical exercise protocol on the expression of DUSP1 in obese humans and analyzed correlations between DUSP1 levels and study population characteristics. Compared to lean subjects, DUSP1 mRNA and protein are highly expressed in the adipose tissue of obese subjects with a concomitant decrease of phospho-p38 MAPK and PGC$1 \alpha$; the two downstream targets of DUSP 1 and an increase in the levels of IL- 6 and TNF- $\alpha$ inflammatory markers. High levels of DUSP1 correlated positively with BMI, percent body fat, blood pressure, triglycerides and $\mathrm{C}$-peptide $(\mathrm{P}<0.05)$. Our data provide for the first time evidence that physical exercise significantly attenuated DUSP1 expression with an increase in PGC-1 $\alpha$, and improvement of the inflammatory and stress responses. Given that both DUSP1 and PGC-1 $\alpha$ have been linked to cancer, their modulation by physical exercise can be considered as a non-pharmacological approach and thereby, mitigating the risk for cancer development in obese population.

Published: 24 February 2014

Deptartment of Biomedical Research, Dasman Diabetes Institute, Dasman, Kuwait

@ 2014 Khadir et al; licensee BioMed Central Ltd. This is an Open Access article distributed under the terms of the Creative Commons Attribution License (http://creativecommons.org/licenses/by/2.0), which permits unrestricted use, distribution, and reproduction in any medium, provided the original work is properly cited.
doi:10.1186/2051-1426-2-S1-P5

Cite this article as: Khadir et al.: Overexpression of the cancer-related DUSP1 gene in human obesity and its modulation by physical exercise. Journal for ImmunoTherapy of Cancer 2014 2(Suppl 1):P5.
Submit your next manuscript to BioMed Central and take full advantage of:

- Convenient online submission

- Thorough peer review

- No space constraints or color figure charges

- Immediate publication on acceptance

- Inclusion in PubMed, CAS, Scopus and Google Scholar

- Research which is freely available for redistribution Submit your manuscript at
www.biomedcentral.com/submit C Biomed Central 